\title{
THE ECONOMIC IMPACT OF COLLEGES AND UNIVERSITIES
}

by

John J. Siegfried, Allen R. Sanderson, and Peter McHenry

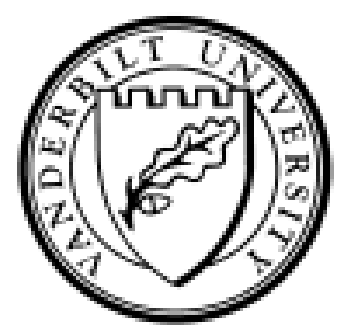

Working Paper No. 06-W12

May 2006

\section{DEPARTMENT OF ECONOMICS \\ VANDERBILT UNIVERSITY \\ NASHVILLE, TN 37235}

www.vanderbilt.edu/econ 
May 26, 2006

\title{
THE ECONOMIC IMPACT OF COLLEGES AND UNIVERSITIES ${ }^{1}$
}

\author{
By \\ John J. Siegfried (Vanderbilt University) \\ Allen R. Sanderson (University of Chicago) \\ Peter McHenry (Yale University)
}

\begin{abstract}
This essay describes methodological approaches and pitfalls common to studies of the economic impact of colleges and universities. Such studies often claim local benefits that imply annualized rates of return on local investment exceeding 100 percent. We address problems in these studies pertaining to the specification of the counterfactual, the definition of the local area, the identification of "new" expenditures, the tendency to double count economic impacts, the role of local taxes, and the omission of local spillover benefits from enhanced human capital created by higher education, and offer several suggestions for improvement. If these economic impact studies were conducted at the level of accuracy most institutions require of faculty research, their claims of local economic benefits would not be so preposterous, and, as a result, trust in and respect for higher education officials would be enhanced.
\end{abstract}

\footnotetext{
${ }^{1}$ The authors gratefully acknowledge financial support from the Andrew W. Mellon Foundation. Malcolm Getz, Paula Stephan and two anonymous referees provided useful comments on an earlier draft. Morgan Wiener suggested the topic to us. She wrote an undergraduate honors thesis (Wiener, 2003) on it at Vanderbilt University.
} 


\section{The Economic Impact of Colleges and Universities}

Colleges and universities often claim they create jobs, boost tax revenue and stimulate the local economy. The purpose of many of these economic impact studies is to articulate the value of an institution of higher education, including spillover effects, often to help the institution compete for state funding (or resist cutbacks), maintain taxexempt status, obtain a subvention, fend off criticism, or bolster fund-raising.

The purposes of this paper are to describe methodological approaches and pitfalls common to these impact studies, and to suggest more productive ways to think about the local economic impact of colleges and universities. We do not wish to vilify unduly the colleges that conduct studies of their economic impact, but we believe that the nature of the fundamental mission of colleges compels them to apply high standards of transparency and accuracy in studying themselves.

Subsequent sections discuss the extent to which colleges and universities produce and disseminate impact studies, summarize findings of these studies and evaluate their methodological underpinnings. We offer suggestions for how to improve such reports.

\section{Economic Impact Studies}

Newspapers are replete with estimates of purported economic impacts of the opening of a casino, a trade show or a national political convention. Some accounts describe negative impacts - property damage caused by Hurricane Katrina or the closing of a local auto assembly plant. Claims of enormous economic gain are ubiquitous in the sports world as well. The National Football League touts the value to a metropolitan area 
of hosting its Super Bowl game at over \$300 million. Promoters claim that a new baseball park is worth seven-figures in dollars and five-figures in jobs. In some cases these claims are harmless self-promotion, but in many instances exaggerated impact studies are used to secure public funding that competes with other social agendas.

With respect to colleges and universities, Caffrey and Isaacs (1971) produced a systematic template to organize the measurement of economic impacts. Since 1971, the number of impact studies has grown, and innovations have added to their complexity and breadth. The basic procedure is to sum expenditures of the college community (students, faculty, staff and visitors) created by the presence of the institution and apply multipliers to account for the interdependency of economic activity in a local economy. The result is an estimated "local economic impact." This common dollar figure often appears in the headline of the report, is usually in the millions (often reaching billions) of dollars, and is frequently complemented by an estimate of job creation. For example:

- “Loyola University Chicago generated a \$1.04 billion economic impact and created or sustained nearly 15,000 jobs in the Chicagoland area in1994.” [Chicago College News. August 1995, 4(12): pp. 1, 4]

- 'In addition to the $\$ 9.7$ billion in 'output impact' generated by the University of Georgia System, public higher education is responsible for 2.8 percent of Georgia’s workforce, or 106,831 full- and part-time jobs.” [www.gatech.edu, January 18, 2005]

Inputs into a college impact analysis include: direct employment and payroll, less federal taxes; expenditures for equipment, supplies and services; construction costs; spending in the local community by faculty members, administrative staff and students; public and private support of research grants and contracts; tuition and fees paid by students from outside the local area and by local students who would alternatively have attended college elsewhere; and expenditures by visitors, including alumni, who visit the 
campus for academic and/or athletic events. Universities with medical centers include corresponding expenditures at their hospitals. Multipliers are applied to these sums to account for indirect and induced impacts. Calculations follow a similar pattern:

- "The University of Maryland generates $\$ 5.93$ of economic activity for each dollar appropriated by the legislature, for a statewide effect of nearly $\$ 1.8$ billion.” [www.inform.umb.edu/nowandthen/news/econoimp.html, February 2002]

- "For every $\$ 1$ in state appropriations for the university, the University of Oregon generates nearly $\$ 10$ in additional expenditures.” [www.our.edu, 2004]

Some studies take credit for in-migration of students (from out of state who come for college and remain) as well as incremental lifetime incomes and sales taxes paid to the state. Impacts in the form of innovation - "Universities are engines of economic development.” - and technology transfer, enhancement of the quality of the local work force, or improvements in the quality of life (e.g., "Alaska is a better place because of the University.” [www.Alaska.edu/state/reports/impact/impact.html, p. 1, no date]) and public service (e.g., volunteer efforts) are frequently mentioned. Colleges also tout their contributions to local culture - theater, music performances, museums, and art exhibitions, most of which are open to the public - but they are difficult to quantify. Some studies argue that colleges are valuable because they are "stable" components of the economy, less prone to contraction in recessions than other businesses.

There is no comprehensive list of college economic impact studies. In a review completed prior to 1992, Leslie and Slaughter (1992) survey about 60 reports. For this paper, we reviewed the results of another 138 studies done since 1992, covering 241 individual institutions. Because of their reliance on government support, the vast majority of these impact studies are for state universities. 
In addition to Caffrey and Isaacs, and Leslie and Slaughter, other contributions to the college/university economic impact literature include: Beck, Elliott, Meisel and Wagner (1995), who propose new methodologies, attempt to account for short-run and long-run flows, and give alternative ways of thinking about geographic regions; Brown and Heaney (1997), who discuss the traditional "economic-base" approach; Felsenstein (1996), who uses Northwestern as an example of a university's impact on a metropolitan area; and Blackwell, Cobb and Weinberg (2002), who discuss traditional and human capital impacts, and conduct a case study of Xavier University in Cincinnati.

The complexity of impact studies and their emphasis on persuasion leads to more dispersion in measurements than the diversity among colleges would imply, raising doubt about their accuracy. Loyola-Chicago and Northwestern, for example, are similar in size and located within a few miles of each other. While Loyola estimated its local impact as \$1.04 billion in 1994 (\$1.42 billion in 2006 dollars), Northwestern claimed only \$145 million in $2006^{2}$, an order of magnitude less. Consider some standardized measures of impacts that should vary modestly among colleges. The multipliers for job impacts ${ }^{3}$ in 98 studies range from 1.03 to 8.44 . Many studies report the impact corresponding to a dollar of government spending. In 67 studies reporting this estimate, its value spans from 1.84 to 26 , a range simply beyond belief. The mean is 5.7 , with a standard deviation of 3.79. These measures are particularly sensitive to the proportion of an institution's budget that is paid by government, but have little to do with local economic impact.

\footnotetext{
${ }^{2}$ See < www.northwestern.edu/shared/cms/bin/newscenter/2006/04/economicimpact.pdf >

${ }^{3}$ Some studies submit a multiplier applied to the college's number of employees to estimate the employment impacts of the college. For other studies, where possible, we infer an employment multiplier by dividing the estimated employment impact by the reported number of employees. Some studies apply a multiplier to the college's number of employees, whereas other studies assume a proportionate relationship between college expenditures and induced local jobs.
} 
Leslie and Slaughter (1992) normalize economic impacts by dividing "business volume" by the college budget. We interpret budget as total expenditures. Among 32 of the post-1992 studies we reviewed, the estimated impact divided by budget ranges from 0.87 to 5.52, with a mean of 2.50 and standard deviation of 1.22 . In 90 reviewed studies, the estimated employment impact divided by budget (in \$ million) ranges from 11 to 271, with mean 45 and standard deviation 42 . Although colleges are heterogeneous, the variety is not enough to justify such a large range of estimates.

In the analysis that follows we address common methodological challenges that affect the accuracy and reliability of these estimates.

\section{The Counterfactual}

The key question posed in studies designed to measure the local impact of a college is how much better off are area residents with the institution there than they would be in its absence. "Better off" is usually defined as higher employment, per capita income or local tax revenue. Both common sense and standard regional economic analysis say the proper procedure is to compare economic indicators in the presence of the institution with predictions of those same indicators "but for" the college - that is, compare actual to "counterfactual" outcomes. From this perspective that portion of an institution's economic activity that would remain in the local area even if the institution were not there is not a contribution to the local economy. Few studies of the local economic impact of colleges and universities explicitly articulate such a counterfactual.

The absence of a clear vision of a realistic alternative exposes the risk of using inconsistent counterfactuals that exaggerate the impact of an institution. Moreover, a 
divergence between the area of study and the area appropriate to the multiplier can lead to internally inconsistent estimates.

The extent of economic activity so affected depends on the scope of the relevant area, the capacity of alternative local suppliers of services to substitute for those produced by the institution, and the extent to which consumers would accept alternative suppliers. For example, a university that attracts students who otherwise would enroll at other institutions in the same metropolitan area does not draw many new students or dollars to the area if the other colleges can increase their enrollment. In contrast, an isolated rural college is likely the sole local attraction to its students, and thus reasonably might be credited with virtually all of the impact stimulated by its students' expenditures. The extent to which colleges and universities attract outside money to an area, i.e. sell “exports” or induce "import substitution,” depends on both the origin of their students, and what the students would have done if the college had not been there.

Establishing a counterfactual for a college is challenging. First, institutions of higher education do not appear and disappear quickly. Conceptualizing Boston without Harvard (founded 1636) is difficult. The annual number of colleges opening or closing is modest. Because most colleges start small and grow slowly over time, it is also usually impossible to identify a short period of time over which the difference between the absence and presence of a college on its local area might be discerned.

Second, no one cares about the effect of any economic stimulus on a geographic area void of residents. Interest in impact is a concern about people and their standard of living, in which case the precise relevant population must be identified. This is where many studies of the economic impact of colleges and universities falter methodologically. 
Who, precisely, is of concern? If a college left an area, who would stay, and who would leave? If a new campus were opened that might stimulate economic activity, for example, the University of California-Merced, whose welfare should be measured - the 67,000 Merced residents living in the Imperial Valley before anyone thought of locating a university there, the 100,000 permanent residents who might live there in 2020 when Merced operates at planned scale, or the 130,000 residents, including students, who might live there in academic year 2021? If welfare were measured by the difference between one's income and what one could earn in his or her next best alternative, a general increase in local wages and salaries stimulated by locating the newest University of California campus in Merced would benefit the original residents. But those who move to Merced may or may not find better opportunities there. Similarly, increases in local property values stimulated by the new Merced campus would accrue to those who owned property there when knowledge of the development was released. But these gains would be offset elsewhere in the state to the extent that the new campus in Merced attracts students who would alternatively enroll at other California institutions.

Studies conducted to enhance the political standing of a college naturally promote benefits accruing to local residents who likely would reside in the area even if the college were absent. The institution's in-migrant administrators and faculty already know they are beneficiaries. They either understand that and are loyal allies of the institution already, or expect they would have enjoyed analogous benefits elsewhere. But hardly any economic impact studies separate the effect of the institution on residents attracted to the area by the institution from the effect on those who would have resided there anyway. 
Migration incentives created by a college complicate the identification of local economic impact further. Imagine a university that "creates” 1,500 new jobs, attracting 1,800 new workers to the local area, 300 arriving as members of families of faculty and other specialists migrating to work for the institution. The university touts the addition of 1,500 jobs added to the area, while the residents who would live there anyway face 300 new competitors for other local jobs. While the impact study trumpets additional jobs, those who would have lived there anyway may be worse off, some perhaps newly unemployed, and others employed at wages lowered by an increased labor supply. ${ }^{4}$

On the other hand, it is possible that a college or university attracts ancillary businesses that demand a skilled workforce, affording improved opportunities to the local residents who would have lived in the area absent the college. Such an outcome assumes, of course, that the local labor force is able to land the skilled jobs at the ancillary businesses, probably an impractical assumption if we are contemplating many chemists, computer scientists or engineers working for such businesses.

Third, because the impact of all the economic activity generated by the institution is compared implicitly to doing nothing, the implied counterfactual in most impact studies is the complete absence of the institution. But few decisions are of such an "all or nothing" nature, particularly in academe, where change occurs slowly. When considering the effect of an expansion or contraction of a college, it is the effect of incremental investment that is relevant. The impact implied by "all or nothing” analysis is an average measure, confounding the irrelevant impact of the first 10,000 students with

\footnotetext{
${ }^{4}$ However, when a college or university hires a local resident, the position formerly held by the resident may open up additional opportunities for another local resident, and so on. A number of local residents may secure better jobs through such a "vacancy chain" until eventually someone from outside the local area fills a job in the chain or a vacancy goes unfilled (Chase, 1991). To our knowledge, no college or university impact study has addressed this possibility.
} 
the effect of the last 100 students to enroll. Diminishing marginal returns can create mischief when an average impact of the entire investment in a college or university is inappropriately interpreted as the relevant effect of an incremental expansion.

Fourth, when a college or university hires faculty and administrators who migrate to the area, the size of the community changes. Most individuals have preferences regarding the population size and density of their environment. Larger communities may create positive externalities such as expanded entertainment, recreation, cultural, medical, shopping and dining opportunities. Unfortunately, they also create more congestion, conflict and pollution. ${ }^{5}$ If a college changes the size of its host community (e.g. State College, PA), the debate over the local economic impact of the institution should also consider optimal city size (Getz and Huang, 1978).

Even more important than the challenge of articulating a precise and constant counterfactual implicit for the college or university is the more general issue of the opportunity cost of public or private investment in higher education. A \$100 million infusion of tax revenue to the budget of a state university catering to in-state students might have been directed by the legislature instead to K-12 education, crime prevention, road repairs or even tax relief. There is no reason to expect that the re-circulation of dollars spent on teachers, police or paving contractors has a different indirect effect on the local economy than dollars initially spent on college inputs.

A dollar spent by a college or university may eventually create two dollars of local economic activity. But a dollar spent bowling or for a catfish buffet does the same.

\footnotetext{
${ }^{5}$ Only rarely do the studies consider effects of the college on property values or the value of amenities and negative consequences that accompany a large agglomeration of young adults and complementary commercial activities, including bars and football stadiums, in a concentrated area. Gumprecht (2005) catalogues various effects a college has on its host community.
} 
One difference between colleges and other establishments is the extent to which initial expenditures of colleges and universities attract new money into an area.

Not all colleges and universities are alike in this regard - some attract much new money to an area, while others attract little. Vanderbilt and the University of Wyoming enroll an entire student body destined to attend a non-local college if those two institutions do not exist. ${ }^{6}$ Other colleges, e.g., Amherst or UCLA, enroll many students who would attend a different institution in the same state (e.g., Williams or Berkeley) if their first choice were not available. Each college or university must be examined closely to determine the extent to which the revenue it collects would remain in the defined local area if the institution did not exist.

Perhaps partially in response to this critique, some colleges in the same area form groups and measure their economic impact collectively. This circumvents the substitutes issue, since there might be no existing substitute for the entire group of existing colleges. The eight research universities in Boston are an example. Although Harvard might not be able to claim credit for drawing to Boston students who otherwise would have attended M.I.T. or another Boston research university were there no Harvard, the group of eight has a legitimate claim that they draw out-of-town students to Boston.

\section{Defining the "Local Area."}

To estimate the impact of a college or university on all or some (e.g., those who would have lived there absent the institution) of the residents of a "local area," one must carefully delineate geographic boundaries. Two principles govern the choice of

\footnotetext{
${ }^{6}$ This conclusion is based on a survey of Vanderbilt freshmen, and the fact that the University of Wyoming is the only four-year college in that state.
} 
boundaries. First, the area should fit the purpose of the economic impact study. Second, however delineated, the boundaries should be consistent throughout the analysis.

The appropriate geographic boundary for analyzing local economic impact depends on the question(s) at hand. If a state university wishes to justify a subvention from its legislature, the geographic boundaries should be congruent with the interests of the legislature - e.g., the state's borders. A private college using a study to justify exemption from local property taxes would presumably delineate the area on the basis of the local tax jurisdiction. A research university seeking more media attention might focus on the television reception or newspaper distribution area surrounding it.

Geographic boundaries have two important effects on the analysis. First, only export sales from, or import substitution in, the defined area constitutes "new spending" that would have a significant first-round economic impact. Sales that substitute for other purchases by local residents may increase the apparent economic impact of a college or university, but they will generate an offsetting negative effect elsewhere in the area. For example, if a student from Boston enrolls at Tufts instead of her second choice, Boston University, Tufts generates no net economic expenditure in the greater Boston area.

In contrast, almost all student expenditures in Boulder by University of Colorado students are either exports or import substitution from the perspective of Boulder because there are no other traditional colleges there. If the area of interest is expanded to the state of Colorado, many UC-Boulder students alternatively would have remained in-state and attended Colorado State, Northern Colorado, or Colorado College. As the relevant area expands, the amount of expenditure that is "new" to it declines. The smaller the area 
considered, the larger the proportion of total expenditure that is properly treated as exports or import substitution.

Second, the appropriate multiplier grows as the area under consideration expands. In a narrowly defined perimeter, e.g., Boulder, much of the first-round of expenditures by the University to purchase goods and services leaves the area immediately. ${ }^{7}$ Not only are many of UC-Boulder's vendors located in Denver and Fort Collins, but also many of its employees live and spend much of their disposable income outside Boulder. When UCBoulder’s expenditures re-circulate beyond Boulder, they do not expand Boulder's economy. Viewed from the entire state of Colorado, however, many first-round expenditures on vendors and employees who live in Colorado but outside Boulder remain "local.” The multiplier is largest in a completely closed economy, devoid of leakages.

It is tempting to define the area narrowly so as to maximize the export and import substitution nature of enrollments and spending, and simultaneously use a multiplier that has been derived by following economic activity through a larger, inconsistently defined, self-contained area. Because most college impact studies use “off-the-shelf” multipliers not tailored to the particular area under consideration, they are susceptible to such an analytical sleight of hand. In reality, there is always a tradeoff between the extent of export sales and the magnitude of the multiplier. ${ }^{8}$

\footnotetext{
${ }^{7}$ See below for discussions of first-round expenditures and multipliers. Furthermore, the amenities of a college town, such as Eugene, Oregon, or Chapel Hill, North Carolina, may attract high-value residents, including retirees, whose local expenditures serve as exports.

${ }^{8}$ For example, an impact study by Duke University applies a spending multiplier of 2 to estimate its effect on Durham ("Duke University Economic Impact Year 2000 Report," Duke University Office of Public Affairs, 2003). The multiplier was chosen as representative of other studies, but a multiplier of 2 is more appropriate for studies focused on larger areas (like states) than cities (which experience more leakage outside the area, and thus lower multiplier effects). On the other hand, many impact studies do use regional impact models calibrated to the geographic boundaries used to estimate new money attracted to the area. See, for example: Sedway Group (2001) (studying the University of California-Berkeley), and Barta, Trzebiatowski, Frye, Arnold, and Woods (2002) (studying East Central University in Oklahoma).
} 


\section{Measuring First-Round Expenditures and Avoiding Double-Counting}

Many economic impact studies conducted by colleges and universities apply a regional multiplier to all expenditures by the institution. Such an approach is never valid. It is inconceivable that every dollar of any college’s revenues (and corresponding expenditures) is derived from export (or import substitution) sales. Surely some revenue, if only from a local resident who purchases books at the college bookshop rather than the local Borders, does not represent new money attracted from outside the area.

In order to identify the amount of net new spending a college or university contributes to a local area, it is necessary to measure funds passing by a particular portal, and to ensure they are counted only once. Students and research funding organizations send checks to the university for tuition, university-provided room and board, and for research projects. Thus, one option is expenditures by organizations making payments to the university and other vendors in the local area (e.g., students buying supplies at a local Wal-Mart, or haircuts at a local barber).

A second way to measure the flow is by revenue received by the college or other local vendors. A third way is as expenditures made by the college and financial flows to other local vendors. This method is probably the most practical. The principle here is that the circulation of funds be counted only once. Thus it is improper to count all spending by students plus expenditures by the college or university, because the majority of student spending usually is made to the college or university for goods and services.

The proportion of expenditures that represent export or import substitution sales (thus, money new to the area) usually is determined by classifying revenues flowing into the area into two categories: those that would have flowed into it "but for" the college, 
and those that would not have come to the area absent the college. This proportion is applied to expenditures by the institution plus expenditures made to other vendors by students and visitors attracted to the area by the college. ${ }^{9}$

What should be counted as new first-round economic activity is tuition, room and board, and other spending by students who alternatively would not have attended a local institution, and revenues from students from inside the area who, in contrast, would have instead attended a college elsewhere (import substitution). Research funding that alternatively would have gone elsewhere, and non-student expenditures attracted to the area by the particular college or university - e.g., money spent by visitors attracted to the area by the institution on potential college scouting trips for high school seniors, journeys to attend sporting events, or visits to friends or family attending the institution, by retirees who moved to the area because of the college, or by patients consuming specialized teaching hospital services that are not available from alternative local medical centers, should also be included. ${ }^{10}$

The challenge of identifying first-round expenditures that are either export or import-substitution increases as an institution grows more complex. At research universities, for example, it is necessary to separate externally funded research

\footnotetext{
${ }^{9}$ This approach assumes that the college spends exactly the revenues it receives each year. To the extent that the institution spends more than it receives in annual revenues, as is the case nearly everywhere, "export sales" are understated, because the deficit must be covered by drawing on endowment earnings, and the proportion of endowments that represent funds that would have been spent in the local area if they had not been contributed to the college is likely quite small.

${ }^{10}$ The revenues and expenditures of university hospitals usually dwarf the rest of the institution. Seldom do medical center expenditures contribute much to local economic development, however. Teaching hospitals usually are surrounded by other acute care medical facilities. In such circumstances, were the university hospital to evaporate, most of the medical services provided by it would be assumed by other local hospitals. Only patients with specialized medical problems would likely turn to hospitals outside the area. Thus, most university hospital expenditures should not be included in the first-round of expenditures, perhaps an exception being isolated university hospitals that serve broad geographic areas in the plains and mountain states.
} 
expenditures from instructional expenditures, and assess the extent to which various research expenditures would have occurred locally "but for” the university. It is likely that most federal research expenditures are appropriately treated as export sales.

If the appropriate criterion for evaluating economic impact is the welfare effect on residents living in the area were the college or university not there, then, quite importantly, none of the payments to in-migrants (faculty and specialized staff, such as librarians and computer specialists) should be counted in the first round of expenditures, because those in-migrants are not part of the "but for" population. The second and subsequent rounds of expenditures passing through these employees and that occur within the local area, however, should be counted.

If the flow of funds affecting local impact is measured by college expenditures, gross payroll overstates the effect on those residents who would live there anyway because it includes the pay of in-migrant employees who would not live there "but for" the institution, and because some employees who do live there spend part of their income elsewhere. For example, most federal income and payroll taxes are not spent in the area. Thus, it is more appropriate to use disposable income plus local (sales, income and property) taxes to measure first-round expenditures that affect the local area, and exclude part of the disposable income of employees who live elsewhere for all or part of the year. Colleges and universities have another characteristic that can cause double counting: they sell products and services to their own employees, or hire their "customers,” as student-workers. Colleges typically sell lunches, books and supplies, and athletic tickets to their employees. Universities with hospitals often self-insure employee medical benefits and create incentives for employees to consume medical services at 
university facilities. In such cases, compensation of all employees overstates expenditures that move on to a second round locally because a portion of the fringe benefits are spent "internally" within the university, thus constituting the source of funds for the salaries, wages and fringe benefits of other employees of the institution. Including such internal transactions may lead to non-trivial double counting.

Student-worker employees of universities seldom buy a market basket of goods and services typical of a local resident. Rather, they spend more on tuition, fees or student expenditures at local businesses that often are accounted for independently in the same study. To the extent that student expenditures are included in college expenditures, the student-worker payroll is double-counted. Similarly, charitable donations from faculty and staff to the institution that employs them should be excluded from first-round expenditures because such donations are transferred back to the employer as revenues rather than spent elsewhere in the local economy.

Construction and other investment spending require special treatment in impact studies. If construction on a state university campus is financed via a capital expenditure budget, and the opportunity cost of building, say, a new student residence hall is the resurfacing of roads in the same geographic area, the construction expenditure is not net new spending. If, on the other hand, investment in educational facilities is financed from outside the area (say, by federal support), reflecting no local opportunity cost, the expenditures should be included because they represent new economic activity for the local area, even if there is an opportunity cost of equivalent value sacrificed elsewhere. 


\section{$\underline{\text { Multipliers }}$}

Two approaches are used to convert an injection of first-round expenditures into the total impact of an institution. Both capture the idea that local expenditures new to an area create income for other firms and individuals, and they, in turn, spend some of their added income locally, thereby "multiplying” the initial infusion. The first approach uses a comprehensive model of a local or regional economy to predict economic activity on the basis of a description of the local economy fed into the model. Then an alternative prediction is made after excluding the college or university from the model. The difference between the predictions is the impact of the institution on the local area.

The second approach applies a numeric multiplier to new expenditures attracted by the institution. ${ }^{11}$ The advantage of using a regional impact model rather than a numeric multiplier is that it is possible to change parameters to suit the circumstances. The advantages of a simple numeric multiplier are cost and convenience. Regional models used to estimate the local impact of new expenditures in an area are calibrated on the basis of the average interactions among all economic agents in the area. ${ }^{12}$ They assume that new expenditures are distributed as the average of historical expenditures.

There are several reasons to suspect that the coefficients relating inputs to outputs in a regional economic model may be inappropriate for estimating the local impact of a college or university. First, if local expenditures of colleges and universities differ from the average pattern of expenditures in the area (perhaps colleges buy more paper and

\footnotetext{
${ }^{11}$ The multiplier should reflect the ratio of the difference in the predictions of economic activity derived from the regional economic model estimated with and without the college or university included, to direct expenditures new to the area.

12 There are three popular models. RIMS II (Regional Input-Output Modeling System) is by the Bureau of Economic Analysis. IMPLAN and REMI are commercial modeling programs. In many states other custom-built region-specific models are also available.
} 
fewer trucks than other businesses), the regional economic model may distort the forecast of local economic impacts. Second, if the pattern of incremental local expenditures differs from the pattern of average local expenditures (perhaps because incremental expenditures contain less infrastructure content than average expenditures) the use of average inter-industry interactions imbedded in a regional economic model will distort the estimate. Third, the outputs of a college or university - individuals with innovative and technical skills, and new technology itself - are intended explicitly to alter a regional economic model's coefficients, thus rendering obsolete the model's estimated relationships between inputs and outputs in the local economy. Fourth, the coefficients in the model often assume that preferences of residents for purchasing goods and services in a "college town" match those of residents in other areas.

Regional multipliers usually have a magnitude around two (Elliott, Levin, and Meisel, 1988, p. 26). The size of the multiplier varies with the extent of the local area. Among impact studies we reviewed are 19 separately reported expenditure multipliers, ranging from 1.34 to 2.54, with a median of 1.7. For 21 impact studies that separately report an employment multiplier (including 16 of the 19 institutions reporting an expenditure multiplier), the multiplier ranges from 1.32 to 4.75 , with a median of 1.8 .

Occasionally, colleges or universities engage in a sleight of words that exaggerates the multiplier. The crafty statement that “...the University of Maryland generates $\$ 5.93$ of economic activity for every dollar appropriated by the General Assembly, for a total statewide effect of nearly $\$ 1.8$ billion” may be accurate, but it is misleading. It implies that every dollar spent on the university returns $\$ 5.93$ to the state annually, for an annual rate of return on state investment near 500 percent. When 
Treasury bills return under four percent a year and stock returns of 15 percent bring joy to investors, a 500 percent annual rate of return sounds too good to be true. And, of course, it is, because it attributes all of the return from the university's myriad activities to the small portion of its budget contributed by the state. It implies that absent the state's contribution, there would be no University of Maryland, and nothing would move in to replace its services, not Towson State, Johns Hopkins, or Hood College.

\section{Local Taxes}

Tax considerations regarding colleges and universities may also affect their surrounding areas. Most not-for-profit institutions are exempt from local property taxes. To the extent that it places a burden on local public services and replaces otherwise taxpaying property, a college or university creates an added burden on other taxpayers in its area. For example, Pittsburgh has challenged the tax-exempt status of an apartment building Duquesne University purchased with the intention of using it as a dormitory, therefore taking it off local property tax rolls. The conversion would cost the city about \$350,000 in lost property taxes annually (“Cities Challenging University Tax Status," cnn.com, March 16, 2004).

Many colleges and universities make "in-lieu-of-taxes" payments, and provide private services such as police protection and trash disposal. In 1989, eleven percent of university communities received payments in lieu of taxes from their universities; 38 percent of cities with fewer than 25,000 residents received payments in lieu of taxes (Gumprecht 2005, page 44). To the extent that “in-lieu-of” payments exceed the remaining burden of local public services not provided by the institution (e.g., the 
University of Chicago police patrol an area larger than just the campus; Davidson College operates a volunteer fire department that also serves the town; and Northwestern University maintains its campus water and sewer lines), tax considerations even might be an advantage to surrounding residents.

Although college property usually is exempt from local taxes, the value of private property surrounding most institutions is enhanced relative to its likely value in the absence of the college by competition for access to provide services to students and staff. The additional property taxes collected from this enhanced value helps to offset taxes foregone on exempt property. Rising property values are not welcomed by all native residents, however, particularly those who do not own homes.

The net impact of local taxes both paid and avoided, services provided in lieu of taxes, and changes in property values in the local area are complex and often contentious town-gown issues, and are seldom considered in impact studies.

\section{Local Spillover Benefits from Enhanced Human Capital}

Although colleges produce consumption services, such as entertainment, status and culture, their basic purpose is to enhance human capital - to create and foster graduates' skills, talents, curiosity, imagination and creativity. Everything else the same (e.g., new expenditures attracted to the area), one would expect a college that produces human capital to have a larger impact than a sports venue or a manufacturing facility. The remaining question is the extent to which that effect is local.

Economists have long recognized that returns to investments in higher education differ when viewed from the perspective of society than from the narrower self-interest of 
an individual. One difference is in cost burdens: society typically subsidizes a portion of the investment individuals make in higher education, so investment costs to an individual fall short of total opportunity costs of a college education. A second difference is that dividends from human capital investment may accrue to society and the individual in different ways. For an individual, the primary benefit is a higher future earnings stream. For society, it might be aggregate earnings, but better health, social cohesion and aggregate growth through technology and ideas might be important effects as well. ${ }^{13}$

Bluestone (1993) argues that incremental future incomes of college graduates who stay in the area should be counted in local impact. ${ }^{14}$ Little of this income, however, would go to people who would have populated the area "but for" the college. Consequently, earnings of migrant students who join the local labor force after graduation should be excluded. Moreover, only incremental earnings of local residents should be counted.

In addition to direct human capital effects, a college may generate indirect human capital impacts by increasing the overall local education level. This may have beneficial indirect effects on those who would live in the area without the college present. Possible social benefits of education include the enhancement of productivity and earnings that spill over to local residents who themselves did not attend college, reduced crime, improved public health (and lower medical costs), and greater civic responsibility. Spillover benefits occur if more highly educated workers enhance the productivity of other workers. Evidence based on cross-section regressions of individual earnings on

\footnotetext{
${ }^{13}$ The notion that education enhances social cohesion has been in the economics literature since Adam Smith (1776, BK. V, CH. I, PT. III, Article II). For examples of the link between aggregate education and growth in the economics literature, see Lucas (1988) for theory and Glaeser et al. (1995) for empirics. ${ }^{14}$ Several subsequent college impact studies have claimed graduates' future earnings as college impacts. Bluestone studied the University of Massachusetts, Boston. Impact studies for Arizona State University, University of Maryland system, and Michigan public universities also have included human capital.
} 
individual characteristics (including educational attainment) and the average level of education in a local area suggests that this phenomenon is real, at least on a national basis (Rizzo, 2004). Rauch (1993) found that large social benefits of education are capitalized into wages and housing prices. More recent studies attempt to account for the fact that local education levels do not evolve randomly. Moretti (2004) finds that a percentage point increase of college graduates in a community's workforce increases wages of local high school dropouts by 1.9 percent, high school graduates by 1.6 percent, and other college graduates by 0.4 percent, for a weighted average effect of 1.3 percent. In contrast, Acemoglu and Angrist (2000) find little evidence of local productivity spillovers from increased education. After reviewing the literature, Lange and Topel (2004) conclude that there may be productivity externalities from the accumulation of local human capital, but they are difficult to quantify.

It is also difficult to quantify the effects of education on crime, health, and civic responsibility, but there is growing evidence that these effects are meaningful. Lochner and Moretti (2004), controlling for feedback effects of crime on education, estimate that differences in educational attainment between black and white men explain 23 percent of the black-white difference in incarceration rates. Breierova and Duflo (2002), and Currie and Moretti (2003) find that higher maternal education improves infant health. Milligan, Oreopoulos, and Moretti (2004) find a strong positive effect of education on voting in the U.S., and that more educated adults have better information about election issues.

Spillover benefits that manifest themselves in higher earnings of individuals other than the graduates themselves can be added to direct local economic effects. Groen (2004) estimates that, on average, for students originally from elsewhere, ten percent are 
likely to reside in the state where they attended college 10-15 years after graduation. Using an estimate of the number of college educated workers attracted to an area annually by the presence of a college, it would be possible to calculate the cumulative annual percentage increase in the local workforce caused by the college, if there were no offsetting effects. Offsets, however, are likely. Unless Emory, Spellman and Georgia Tech graduates who take jobs in Atlanta fill new positions that would not have otherwise existed, graduates of South Carolina, Duke, Auburn or Florida State who otherwise would have taken those jobs in Atlanta do not move there (Brown and Heaney, 1997; Krieg, 1991, p. 72). If employers locate in Atlanta only because of the supply of college graduates there, the employers must believe it is difficult to persuade graduates of Atlanta universities to move elsewhere. However, if college graduates are mobile, the net effect of a college on the proportion of the workforce holding a college degree is close to zero, although there will be more Emory, Spellman and Georgia Tech alumni in Atlanta than would otherwise reside there. The argument that a college or university enhances the education level of the local workforce is cogent only if its presence attracts new employers to the local area. ${ }^{15}$ Bound et al. (2004) find that the link between a state’s production of higher education and its stock of human capital is weak.

It is difficult to determine what metric to multiply by Moretti’s estimated effect on wages (1.3 percent per one percent increment in the proportion of the workforce with a college degree). The proportion of an institution's graduates who remain in the area surely varies by location - it could not be 10 percent at Dartmouth because there are not enough jobs in Hanover, New Hampshire, to absorb ten percent of the graduates - and

\footnotetext{
${ }^{15}$ In a few cases the location of university science or engineering faculty and/or Ph.D. students may attract an employer to a particular area, but these occurrences are few and far between in the universe of about 2,000 four-year colleges and universities.
} 
the net effect is likely to be much less than 10 percent, on average, because the local college graduates who stay in the area crowd out graduates from other institutions who otherwise would have migrated in. Although spillover effects of education on the productivity and earnings of non-college graduates may be substantial, as Moretti estimates, the effect on local areas is likely modest because college educated workers would be attracted to the area regardless of their alma mater. Similarly, while spillover benefits of education on crime, health, and civic responsibility may be real and substantial, it is also not likely that they depend critically on the presence of a local college or university.

\section{Conclusion and Recommendations}

We see two reforms for more transparent and useful college economic impact studies: presentation and substance. Regarding presentation, studies of public universities should stop claiming “For every \$1 the state legislature spends, the university returns $\$ X$ dollars to the state...” At best such statements are meaningless. At worst, they may delude decision-makers into thinking (incorrectly) that the marginal return on investment in higher education is several orders of magnitude more than returns on other public investments. If the returns to higher education were as high as these statements imply, states and the private sector would be building universities frantically.

Second, colleges should stop reporting a single impact in two formats so as to mislead readers into thinking benefits are larger than reality. Financial impact and jobs impact are alternative measures of one concept. The value of economic activity to a local area occurs when the activity employs local residents, who use their income to enhance 
their welfare. Moreover, expenditures by employees (e.g., on local taxes or for charity) are not additions to the financial impact, but rather are included in payroll. Yet, many studies report them separately, tempting readers to infer that they are additions to the impact generated by applying a multiplier to local spending that includes payroll.

Regarding substance, there are even more opportunities to improve impact studies. First, every impact study should articulate the counterfactual it uses at the beginning of the report, and thereafter it should adhere to it relentlessly. If the study compares economic activity in the area to a prediction of what would have occurred "but for" the college, it should omit the benefits that accrue to in-migrants.

Second, the reported impact should relate to the issue at hand. If the college or university is asking for a zoning variance to build a new residence hall, the economic effect should relate to the incremental increase in the number of students the hall is planned to accommodate rather than to the entire effect of the college. While the impact of the entire institution may be impressive, and so good for rhetoric, it is disingenuous to use it to justify a policy that accommodates an incremental change.

Third, the pertinent geographic area should be articulated explicitly, and both the multiplier used and the extent to which revenues reflect exports and import substitution should relate precisely to its boundaries. It is inappropriate to use a small area to identify a large proportion of revenues as export, and then adopt an off-the-shelf multiplier that has been calibrated on the basis of a larger area that experiences few leakages.

Fourth, first-round expenditures should exclude amounts that would have been spent in the local area "but for" the college. Expenditures at university hospitals are 
likely the largest of these. Another is money spent by students who otherwise would have attended another college in the same area.

Fifth, the appropriate multiplier must be applied to each type of expenditure. Research expenditures on materials imported into the area have a multiplier of zero. Any multiplier exceeding two for an area less than an entire state is suspect.

Sixth, expenditures should be counted only once. Students' spending on tuition and the college payroll are one and the same thing: students pay tuition so the college can meet its payroll. The payment of tuition has no effect on the local economy until it is used to meet the payroll and buy other local goods and services.

Finally, an institution may take credit for stimulating the local economy through its spillover effects on the general level of productivity, reduced crime, enhanced health and civic responsibility. Before these claims are valid, however, the college needs to articulate how its presence created the jobs filled by the college graduates. This might be through technology spillovers from research faculty (not students), which, of course, would make it a difficult argument for primarily teaching colleges. New jobs might also arise from lower wages that compensate for attractive amenities that are fostered by the college.

If college impact studies were conducted at the level of accuracy most institutions require of faculty research, we would see fewer preposterous claims like a 2600 percent annual rate of return (“...for each dollar of state support, [Michigan] universities collectively generated \$26 of economic impact.” [“The Economic Impact of Michigan’s Public Universities, SRI International for the Michigan Economic Development 
Corporation (May 2002), page 3]). This would improve public trust in higher education officials.

Most local "economic impact” consists of activity relocated from other places, with little effect on the national aggregate. One community's gain is offset by another's loss. Rearranging resources improves aggregate welfare only to the extent that a new location affords less costly production, say, through the exploitation of agglomeration economies or use of geographically immobile inputs, or tailors the location of output more closely to the geographical distribution of demand. Neither of these situations seems important in higher education.

In contrast, moving resources geographically can improve local welfare. Since a particular community is often the audience of a college impact study, it makes sense to tout local benefits even if they are largely offset by corresponding losses elsewhere. However, the academic mission of colleges compels them to refrain from engaging in rhetoric that places their interests above all other social goals. Implementing our recommendations in economic impact studies would help colleges align their public communication with the mission statements in their charters. 


\section{References}

Acemoglu, Daron and Joshua Angrist. 2000. "How Large are the Social Returns to Education? Evidence from Compulsory Schooling Laws." NBER Macroeconomics Annual. Ben S. Bernanke and Kenneth Rogoff, eds. pp. 9-59.

Barta, Suzette, Susan Trzebiatowski, Jack Frye, James Arnold, and Mike Woods. 2002. "The Economic Impact of East Central University on the Economy of Pontotoc County, Oklahoma.” Oklahoma Cooperative Extension Service, Oklahoma State University.

Beck, Roger, Donald Elliott, John Meisel, and Michael Wagner. 1995. "Economic Impact Studies of Regional Public Colleges and Universities.” Growth and Change. 26:2, pp. 245-260.

Blackwell, Melanie and Steven Cobb and David Weinberg. 2002. "The Economic Impact of Educational Institutions: Issues and Methodology.” Economic Development Quarterly. 16:1, pp. 88-95.

Bluestone, Barry. 1993. UMASS/Boston: An Economic Impact Analysis.

Bound, John, Jeffrey Groen, Gabor Kezdi, and Sarah Turner. 2004. “Trade in University Training: Cross-State Variation in the Production and Stock of College-Educated Labor.” Journal of Econometrics (July - August) 121(1-2): pp. 143-73.

Breierova, Lucia, and Esther Duflo. 2002. "The Impact of Education on Fertility and Child Mortality: Do Fathers Really Matter Less than Mothers?” MIT Working Paper (March).

Brown, Kenneth H. and Michael T. Heaney. 1997. "A Note on Measuring the Economic Impact of Institutions of Higher Education.” Research in Higher Education. 38:2, pp. 229-240.

Caffrey, John and Herbert Isaacs. 1971. Estimating the Impact of a College, or University on the Local Economy. Washington, D.C.: American Council on Education.

Chase, Ivan D. 1991. “Vacancy Chains.” Annual Review of Sociology 17: pp. 133-154.

CNN.com. 2004. “Cities Challenging University Tax Status,” (March 16, p. 32).

Currie, Janet, and Enrico Moretti. 2003. "Mother's Education and the Intergenerational Transmission of Human Capital: Evidence from College Openings.”

Quarterly Journal of Economics. 118:4, pp. 1495-1532. 
Duke University Office of Public Affairs. 2003. "Durham and Duke: An Analysis of Duke University's Estimated Total Annual Economic Impact on the City and County of Durham.” At 〈http://www.dukenews.duke.edu/2004/02/economics_0204.html/>.

Elliot, Donald S. and Stanford L. Levin, and John B. Meisel. 1988. "Measuring The Economic Impact Of Institutions Of Higher Education.” Research in Higher Education. 28, pp. 117-33.

Felsenstein, Daniel. 1996. “The University in the Metropolitan Arena:Impacts and Public Policy Implications.” Urban Studies. 33:9, pp. 1565-1580.

Getz, Malcolm and Yuh-ching Huang. 1978. "Consumer Revealed Preference for Environmental Goods.” Review of Economics and Statistics. 60:3, pp. 449-458.

Glaeser, Edward L., Jose A. Scheinkman, and Andrei Schleifer. 1995. "Economic Growth in a Cross-Section of Cities.” Journal of Monetary Economics. 36:1, pp. 117143.

Groen, Jeffrey A. 2004. "The Effect of College Location on Migration of Collegeeducated Labor.” Journal of Econometrics. 121, pp. 125-142.

Gumprecht, Blake. 2005. “Town vs Gown: City-University Relations in the American College Town.” Department of Geography, University of New Hampshire.

IMPLAN. "Minnesota IMPLAN Group, Inc." $<$ http://www.implan.com/other_links.html/>

Krieg, Randall G. 1991. "Human-Capital Selectivity in Interstate Migration.” Growth and Change. 22:1, pp. 69-76.

Lange, Fabian and Robert Topel. 2004. "The Social Value of Education and Human Capital" in The Handbook of Education Economics. F. Welch and E. Hanushek, eds. Amsterdam: North Holland Press. Forthcoming.

Leslie, Larry L. and Sheila A. Slaughter. 1992. "Higher Education and Regional Development," in The Economics of American Higher Education, William E. Becker and Darrell R. Lewis (eds), Kluwer Academic Publishers.

Lochner, Lance and Enrico Moretti. 2004. "The Effect of Education on Criminal Activity: Evidence from Prison Inmates, Arrests and Self-Reports." American Economic Review. 94:1, pp. 155-189.

Lucas, Robert E. 1988. “On the Mechanics of Economic Development.” Journal of Monetary Economics. 22, pp. 3-42. 
Milligan, Kevin, Enrico Moretti, and Philip Oreopoulos. 2004. "Does Education Improve Citizenship? Evidence from the United States and the United Kingdom.” Journal of Public Economics. 88:9-10, pp. 1667-1695.

Moretti, Enrico. 2004. "Estimating the Social Return to Higher Education: Evidence from Longitudinal and Cross-Section Data." Journal of Econometrics. 121, pp. 175-212.

Rauch, James. 1993. "Productivity Gains from Geographic Concentration in Cities.” Journal of Urban Economics. 34, pp. 380-400.

REMI. “Regional Economic Models, Inc.” 〈http://www.remi.com/support/about.html/〉.

RIMS II. "Bureau of Economic Analysis: Regional Economic Accounts.” $\langle$ http://www.bea.doc.gov/bea/regional/rims/〉.

Rizzo, Michael J. 2004. “The Public Interest in Higher Education.” Cornell Higher Education Research Institute Working Paper, WP 56 (November), 53 pp.

Sedway Group. 2001. "Building the Bay Area’s Future: A Study of the Economic Impact of the University of California, Berkeley."

Smith, Adam. 1776. An Inquiry into the Nature and Causes of the Wealth of Nations. E. Cannan, ed. 1994. New York: The Modern Library.

SRI International. 2002. “The Economic Impact of Michigan’s Public Universities.” SRI Project \#: PDH 02-019.

Wiener, Morgan. 2003. A Critical Analysis of Vanderbilt University's 2001 Economic Impact Study. Unpublished, Vanderbilt University (May). 